\title{
鼻汁中蛋白質分析による血管運動性鼻炎様病態をもつ アレルギー性鼻炎の鑑別
}

\author{
北里大学医学部耳咽喉科学教室（主任：設楽揞也教授） \\ 井口芳 明
}

\section{DIFFERENTIATION BETWEEN ALLERGIC RHINITIS AND VASOMOTOR RHINITIS BY ELECTROPHORETIC EVALUATION OF THE PROTEIN IN PITUITA}

YOSHIAKI IGUCHI, M.D.

Department of Otorhinolaryngology. School of Medicine, University of Kitasato, Sagamihara

Application of trichloro-acetic acid (TCA) to the inferior turbinates is being performed at our hospital to treat allergic rhinitis. However, some patients have continous rhinorrhea even though the provocation test after treatment was negative. Electrophoretic studies were performed on the nasal discharge of such continuous rhinorrhea patients to analyze its protein components, albumin and $23 \mathrm{kD}$ protein. The results showed that the pituita in the unimproved cases with negative provocation result was similar in nature to the pituita in vasomotor rhinitis patients.

It was concluded that the proteins in the pituita were not attributable to an antigen-antibody reaction, becouse the provocation test was negative, but they were the result of angiogenic factors (=vasomotor rhinitis). Thus it appears that allergic rhinitis can be classified into two types: genuine allergic rhinitis and allergic rhinitis associated with vasomotor rhinitis. TCA therapy was not effective in the cases of allergic rhinitis with vasomotor rhinitis, because they had a pathophysiological feature of vasomotor rhinitis. Genuine allergic rhinitis can be differentiated from vasomotor rhinitis clinically by measuring albumin and $23 \mathrm{kD}$ protein in pituita. It was concluded that measurement of $23 \mathrm{kD}$ protein concentrations in pituita is effective for determing indications for TCA chemotherapy and evaluating its clinical results.

\footnotetext{
Key words : アレルギー性炎, 血管運野性炎, アルフミン A

ている可能性がある。

しかし実除臨床ては，ダニ,ハウスダスト(以下 H.D.

1986年以来アレルギー性算炎症例に対して $80 \%$ トリ

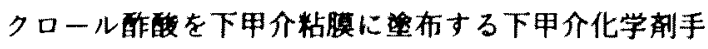

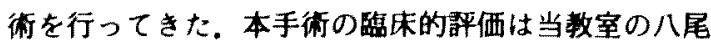

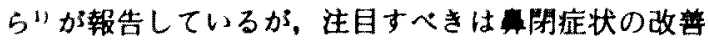

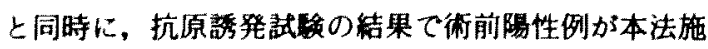

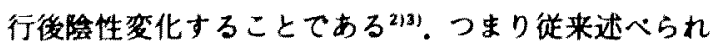
てきたアレルギー性息炎の病䍐とされるI型アレルギ 一反店が下甲介化学剂手術により抑制ないし除去され
とする）を主抗原とする通年性アレルギー性监のな かには完治する症例に加えて，手術後抗原誘発試䟻結 果が坽性化するにもかかからず水棦性基斗症状のみが 持繶する症例が少なからずみられる、すなかち下甲介 化学绪手街てI 型アレルギー反応は取り除かれたとし ても，他の病臨がさらに前面に現われ，従来いわれて きたアレルギー性县㷋症状の一部を継続して示す症例 
がある.

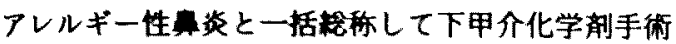
の対象とした应例のなかには嫩密に对象とすることが てきずなおかつその病娒を解明すべき症例があるこ とが考えられる。そこで通年性アレルギー性悠の手 街適底症例を巏密に区別し得る指標を求めることを目 的として县计中の蛋白貝成分の分析を試みた。

\section{対}

北里大学病院耳鹪咽科アレルギー外来を受稿した 㭧者を焦作為に抽出し対象とした。思者には病歴䐍取，

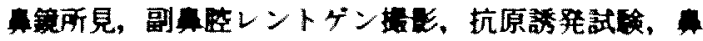

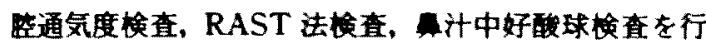

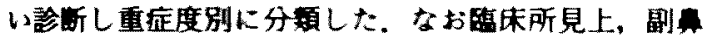

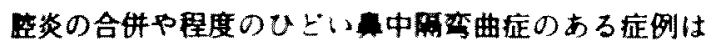
対象外とした。

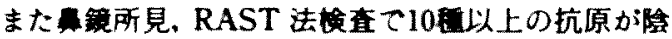

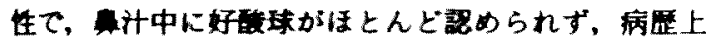

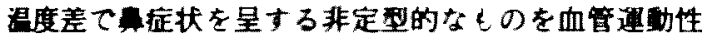
炎とした。

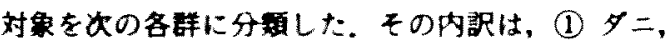

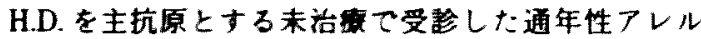

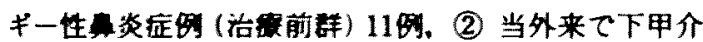

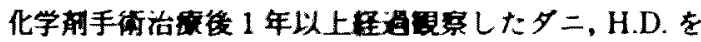

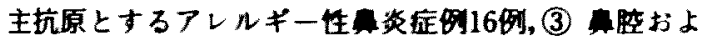

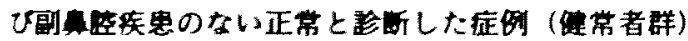

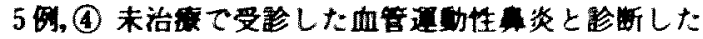
在畔门国とした。

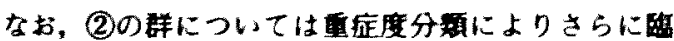

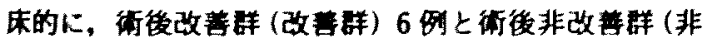
改善群) 10 例の 2 群に分けた。

\section{万法}

1. 应例の重应度分樯法

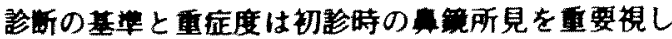
た.

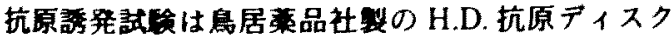

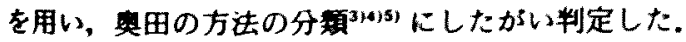

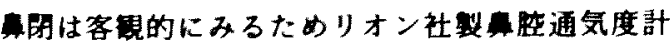
SR-11 を用い, 基啭点として $p=100$ pasc. 吸気時ての 合整抵抗值を求めた。

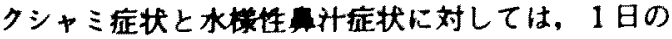
平均クシャミ回数ならびにをかんだ回数て，10回以 上 $(2+), 1$ 回加ら 9 回 $(+), 0$ 回 $(-)$ の 3 評洒基
㳯を定めた，我々が日常臨床てみるアレルギー性算炎 の应状は断続的に起こる抗原暴露によって生じたもの である゙. したがって各应例はさまさまな症状を量し て外来の猃察をうける。そこで受診時の病歴， 内所 見から水棣性计症状が $(2+)$ 以上のものを治䖒前群 の対象と定めた。

2、試料の採取、調整

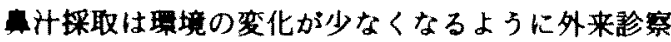
室で午前10時から11時までの時間に、いずれも誘発試 の前に行った。

その方法は前的孔り体温に近い温度に温めた生理

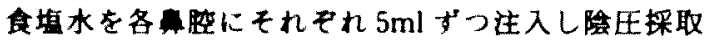
した。このとき前届位をとり热声させて，注入した生 理食场水が咽頍に回らないようにした，採取した算 洗浄洨はその日のうちに $4{ }^{\circ} \mathrm{C} ， 3000 \times \mathrm{g}$ で寀心分部し モの上清を試料とした。試料は湅結保存し実駼は 3 力 月以内に行った。

また蛋白資成分の比较検討のため血清，唾海，源洨 を探取した，血清は血液を $4{ }^{\circ} \mathrm{C} ， 3000 \times \mathrm{g}$ て裎心分崔 し、さらにその上清を500倍希釈し試料とした。睡液は

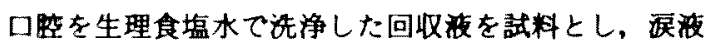
は眼球結膜の生理食塩水による洗浄液を試料とした。

3. 下甲介化学剂手術

アレルギー性算炎の治撩として下甲介化学剂手術を 行ったトトリクロール酢酸を80\%として両則下甲介に 熏布した，その方法は4\%リドカイン，5000倍アドレ ナリンで 内処酒後に，綀巻きの線棒で下甲介表面に 里布しだ2)。

\section{4. 督白定定}

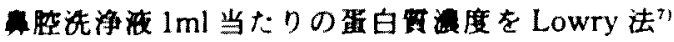

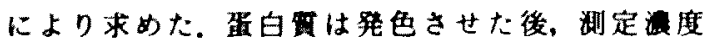
$500 \mathrm{~nm}$ て比色定量した. ウシアルフミン(BSA) 1mg/

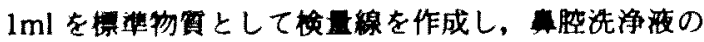
蛋白賏度をBSA 换算として表した。

5. SDS-ポリアクリルアミドゲル電気泳動法(SDS -PAGE)"による蛋白貿成分の分析

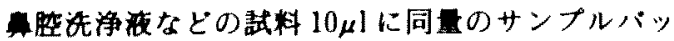

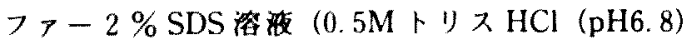
$1.0 \mathrm{ml}$, タリリセリン $0.8 \mathrm{ml}, 10 \% \operatorname{SDS} 1.6 \mathrm{ml}, 2 \beta$ メル カプトタノール $0.4 \mathrm{ml}, 0.05 \%(\mathrm{w} / \mathrm{v})$ プロモフェノ 一ルフルー0.2ml, 来留水 $4.0 \mathrm{ml}$ )を加え武料とした。 $10 \%$ 分矆ダル $(30 \%$ アリリルアミド $-0.8 \%$ ビスアク リルアミド $6.75 \mathrm{ml}, 0.75 \mathrm{M}$ Tris/HCl $-0.2 \% \mathrm{SDS}$ (pH8.8) $10.0 \mathrm{ml}$, 留水 $2.5 \mathrm{ml}$, TEMED $20 \mu \mathrm{l}$, 過硫 
酸アンモニウム $1.0 \mathrm{ml})$ と、 $3 \%$ 洤樎ダル $(30 \%$ アクリ ルアミド $-0.8 \%$ ビスアクリルアミド $1.5 \mathrm{ml}, 0.25 \mathrm{M}$ Tris $/ \mathrm{HCl}-0.2 \%$ SDS (pH6. 8) $7.5 \mathrm{ml}$, TEMED $10 \mu \mathrm{l}$, 過硫酸アンモニウム $1.0 \mathrm{ml}$, 蒸留水 $5.0 \mathrm{ml})$ を作制し泳 動装国に付け，陚料を針付きマイクロシリンジて1 試

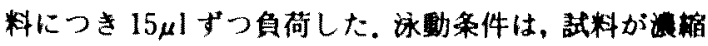
ダル中にあるときは $10 \mathrm{~mA}$ 、分墔ダル中にあるときは $20 \mathrm{~mA}$ で行い，各ゲル中1時間，合計 2 時閶泳助した。

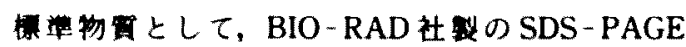
standerds (phosphorylase b $130 \mathrm{kD}$, bovine serum albumin $75 \mathrm{kD}$. ovalbumin $50 \mathrm{kD}$, carbonic anhydrase $39 \mathrm{kD}$, soy bean trypsin inhibitor $27 \mathrm{kD}$, lysozyme $17 \mathrm{kD}$ )用い，武料と同時に西気泳娌しだ。ダルは西

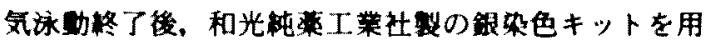

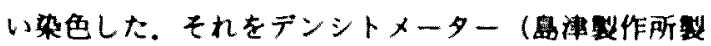
クロマトスキ++CS-910,クロマトパックC-RIA)

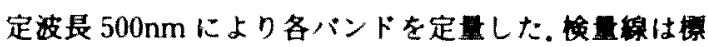

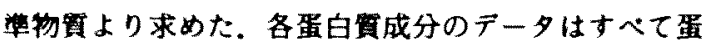
白暂度上蛋白算に对する各成分の百分率でし た.

\section{6. 腺由来蛋白嘪の分析}

外分缐由来と考えられる蛋白䨘成分が留粘膜の腺 組機から分论されていることを証明するため，外分

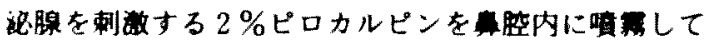

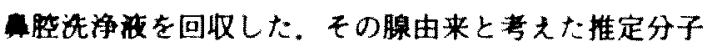

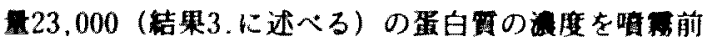
の硫度と比した。

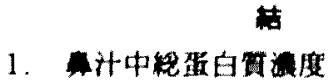

夕二,H.D. を主抗原とする通年性アレルギー性资

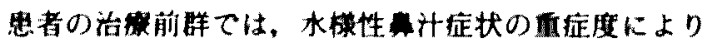

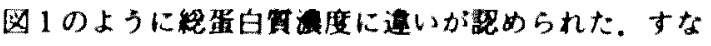

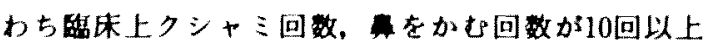
$(2+)$ の姃例 $(102.8 \pm 28.8 \mu \mathrm{g} / \mathrm{ml}$ ) (平均値士畨整偏差) は, $1 \sim 9$ 回 $(+)(58.7 \pm 19.6 \mu \mathrm{g} / \mathrm{ml})$ おう

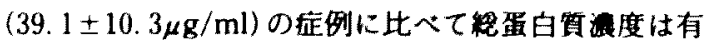
意に增加した。

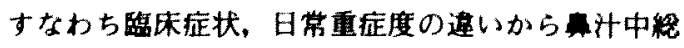
䖝白買度には连いがあった。この結果から，本研究 の治然前群は水棣性计症状が $(2+)$ 以上の症例とし た。

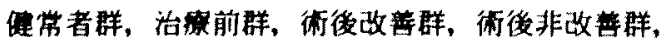
血管理動性炎の總合腹抵抗做扔よび末梢血中好酸

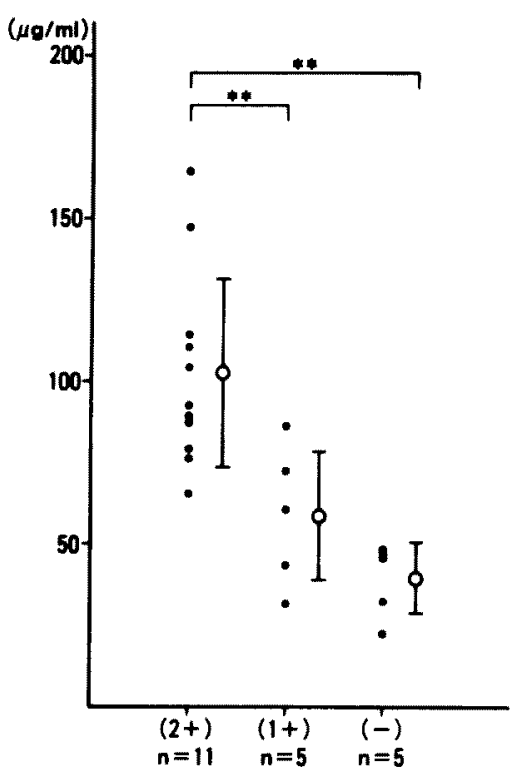

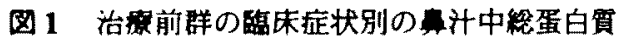
洗度

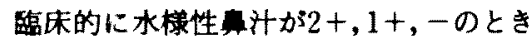

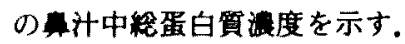

Mann-Whitney 娭定を行った。

(**: $p<0.01$ )

哀 1 对象とした各群の平均総合腔抵抗值と平均 末梢血中好酸球数

$\mathrm{t}$ 榆定を行った. $(*: \mathrm{p}<0.05)$

\begin{tabular}{|c|c|c|}
\hline & 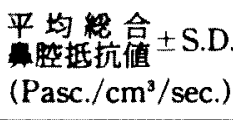 & $\begin{array}{c}\text { 平均血中 } \\
\text { 好福球数 } \\
((\mu \mathrm{S}) \\
\end{array}$ \\
\hline 俚常者 & $0.23 \pm 0.15$ & $137 \pm 86.5$ \\
\hline 治龔前群 & $0.68 \pm 0.56$ & $437 \pm 187.6$ \\
\hline 術後改嘒群 & $0.27 \pm 0.17$ & $266 \pm 105.9$ \\
\hline 術後非改尊群 & $0.71 \pm 0.54$ & $380 \pm 156.1$ \\
\hline 血管惪趿性炎 & $0.20 \pm 0.10$ & $218 \pm 81.4$ \\
\hline
\end{tabular}

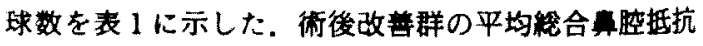
值は治掽前群に比へ有意に減少し, 術後非改善群の抵 抗值は改前群に比べ有意に高值を示した。

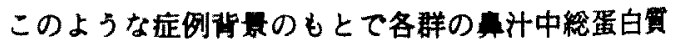
淇度を求めた（図 2 )。治康前群は $102.8 \pm 28.8 \mu \mathrm{g} / \mathrm{ml}$ と高流度を示したが, 術後改善群 $(34.3 \pm 6.4 \mu \mathrm{g} / \mathrm{ml})$ はほ住常者群 $(30.4 \pm 10.2 \mu \mathrm{g} / \mathrm{ml})$ の低浱度に回復し

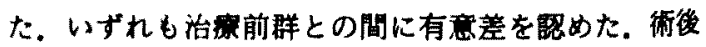




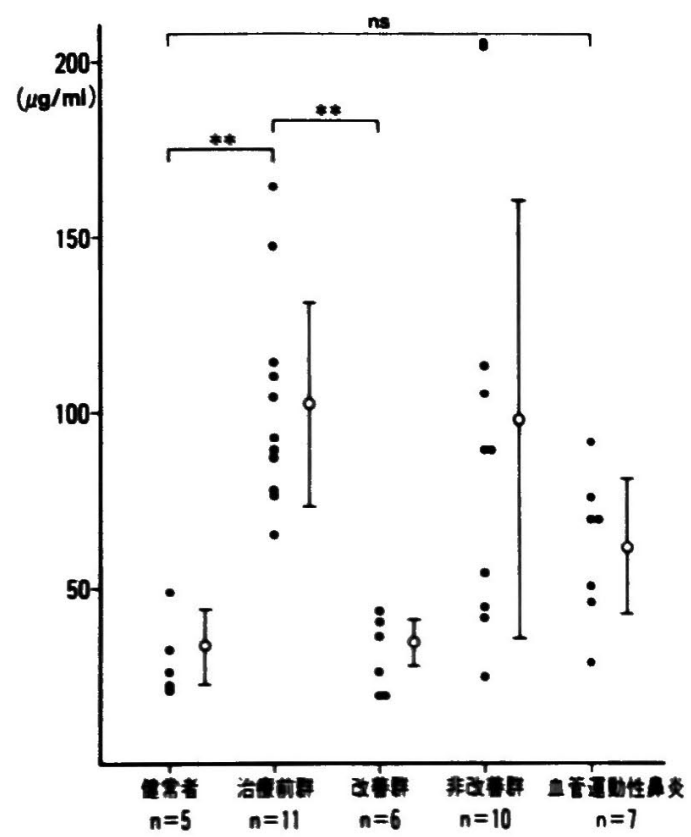

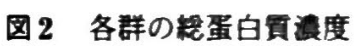

t検定を行った. $(* *: p<0.01, n s$ ：有 意差なし)

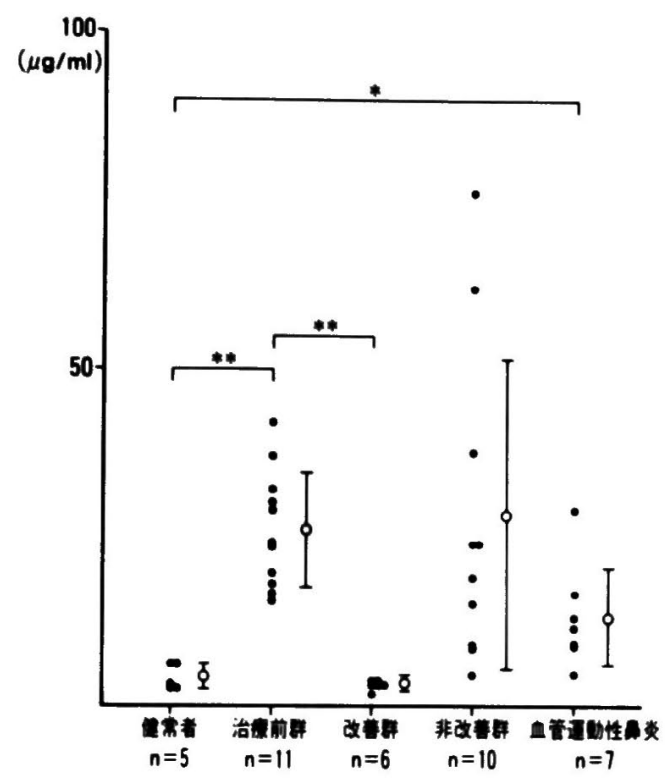

图 3 アルブミンの濃度 $\mathrm{t}$ 検定を行った. $(*: \mathrm{p}<0.05, * *$ : $\mathrm{p}<0.01$ )

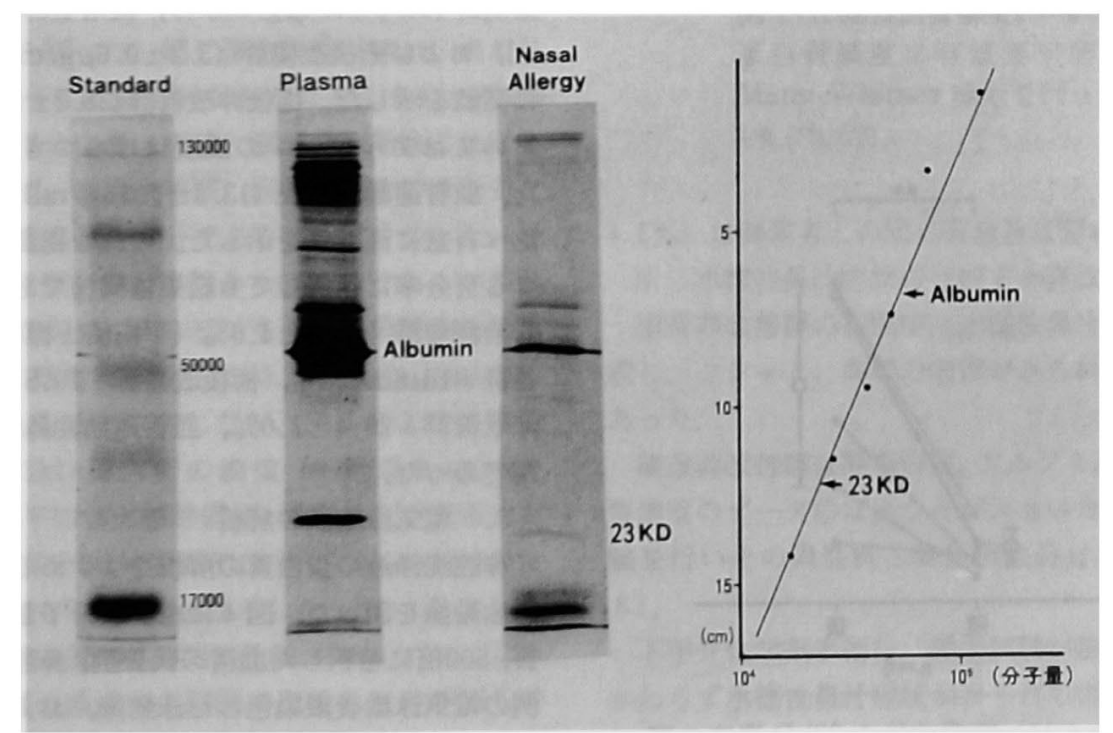

图 4 標準物質, 血清, 悬汁の泳動像とその検量線 アルフミンは血清と鼻计の両者に認められた。㭘量線から $23 \mathrm{kD}$ と計算される蛋白質は鼻斗に認められた。

非改善群 $(97.9 \pm 61.0 \mu \mathrm{g} / \mathrm{ml})$ はデータのばらつきが大 きくなった. 血管運動性资 $(61.9 \pm 21.2 \mu \mathrm{g} / \mathrm{ml})$ は治 嶛前群より低値であるが, 健常者群より高値を示した.
しかし健常者群との間では有意差はなかった。

2. アルフミンの各群間の比較

アルフミンについて各群の濃度を示すと(図 3 ), 治 


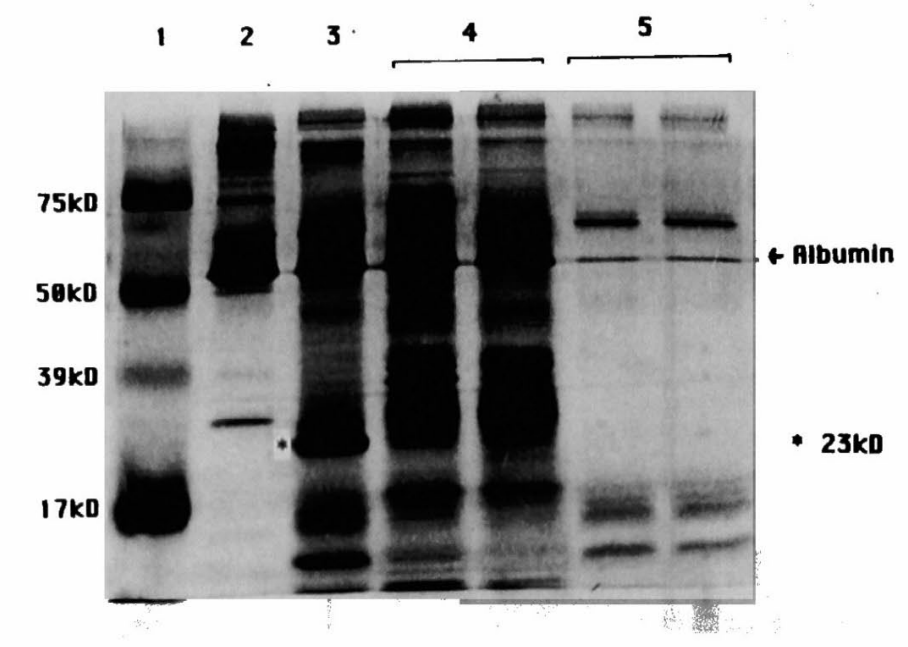

図 5 各試料の電気永動像

試料を同量, 同時に電気泳動し銀染色をした. 1 ：標 準物質，2：500倍に希釈した血清，3：鼻腔洗浄液， 4: 唾液，5：淚液を表す。貫汁の泳動像にみられた $23 \mathrm{kD}$ 蛋白質成分はほかてはほとんど認められなか った.

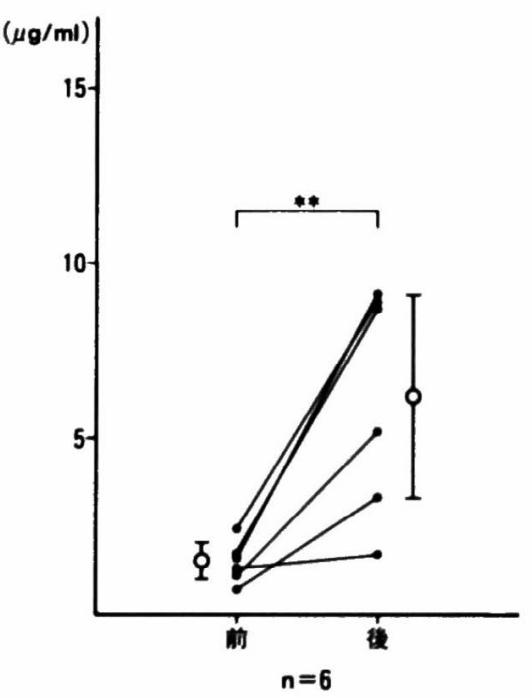

図 6 ピロカルピン噴霧前後の $23 \mathrm{kD}$ 濃度の変 化

健常者に $2 \%$ ピロカルピンを両側の番腔

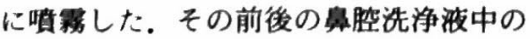
$23 \mathrm{kD}$ の蛋白質濃度をみたところ有意に 濃度は高くなった。外分泌腺が刺激され て濃度が高くなったと考えられる。

$(* *: \mathrm{p}<0.01)$
撩前群 $(26.3 \pm 8.4 \mu \mathrm{g} / \mathrm{ml})$ は, 健常者群 $(4.2 \pm 1.7 \mu \mathrm{g} /$ $\mathrm{ml})$ および術後改善群 $(3.2 \pm 0.6 \mu \mathrm{g} / \mathrm{ml})$ に比へ有意 に高値を示した。術後非改善群 $(28.2 \pm 22.6 \mu \mathrm{g} / \mathrm{ml})$ に おいてはアルプンの濃度はばらつきが大きくなっ た。血管連動性鼻炎 $(13.3 \pm 7.3 \mu \mathrm{g} / \mathrm{ml})$ は健常者群に

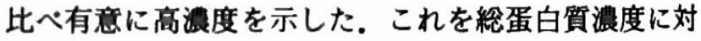
する百分率に換算しても結果は同様であった。すなわ

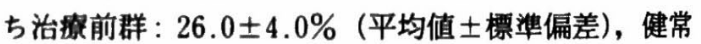
者群: $13.8 \pm 2.6 \%$, 術後改善群 : $10.5 \pm 0.8 \%$, 術後 非改善群: $26.4 \pm 7.0 \%$, 血管運動性鼻炎: $21.1 \pm 8.6$ \%でった。

\section{3. 奄気泳動像の解析}

鼻腔洗浄液の蛋白質の解析をすすめるためにその電 気泳動像を調へた。図 4 に左より分子量測定用標制物 質, 500倍に希釈した血清の代表例, 鼻腔洗净液の代表 例の電気泳動後銀染色した泳動像，および標洀物質よ り求めた桧量線を示す. 血清成分の一部は鼻腔洗浄液 中に移行することが明らかであが, なかでも分子量 66,300のアルプミンは血清, 畺计の両者にみられた. このほか鼻腔洗浄液の泳動像には推定分子量 23,000 (以下 $23 \mathrm{kD}$ と記す)のバンドがみられ，これは 血清の泳動像には鯰められなかった。

$23 \mathrm{kD}$ の蛋白買が鼻粘膜由来であることをみるた 


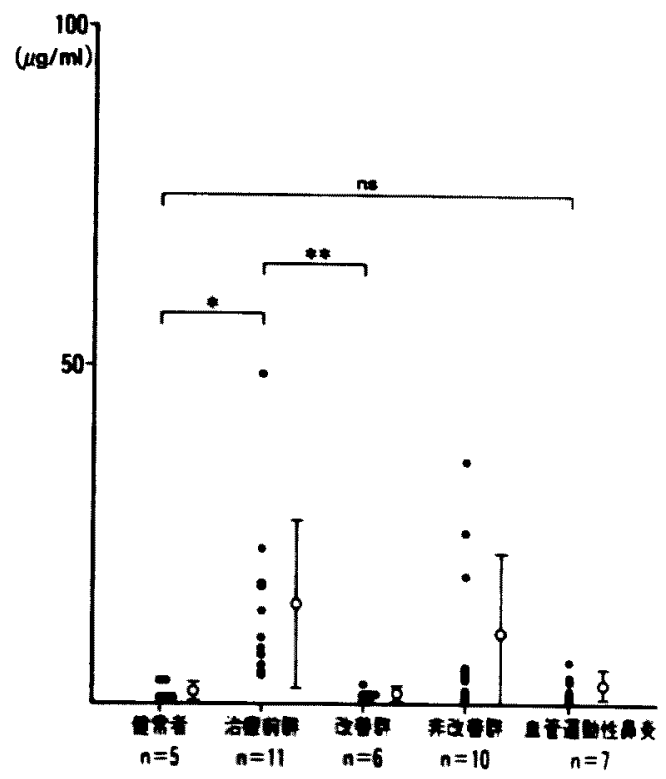

图 $723 \mathrm{kD}$ の蛋白而流度

$\mathrm{t}$ 模定を行った. $(*: \mathrm{p}<0.05, * *$ * $\mathrm{p}<0.01, \mathrm{~ns}$ ：有意差なし）

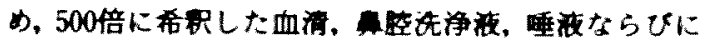

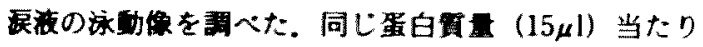

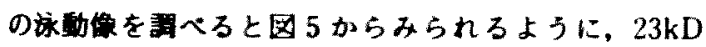

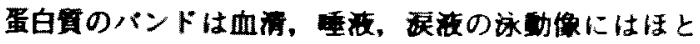

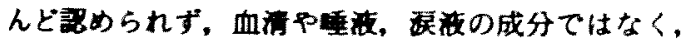

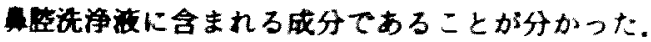

さらに23kD蛋白霓か腺からの分站てあるか否か

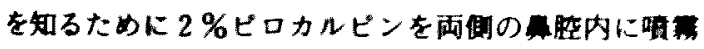

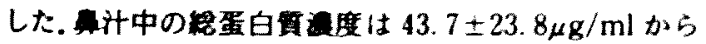
$118.0 \pm 60.4 \mu \mathrm{g} / \mathrm{ml}$ と增加したが，图6のように血需 後の勀中 $23 \mathrm{kD}$ 蛋白の度 $(6.2 \pm 2.9 \mu \mathrm{g} / \mathrm{ml}$,

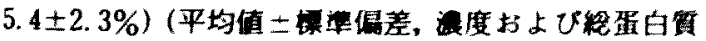

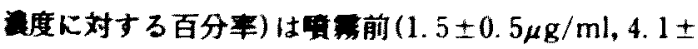
1.8\%)に比べて有意に高值を示した。

\section{4. $23 \mathrm{kD}$ 蛋白買の各群間の比较}

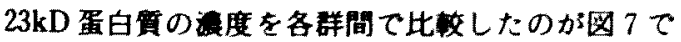
ある。治樭前群 $(14.6 \pm 12.3 \mu \mathrm{g} / \mathrm{ml}, 14.0 \pm 11.0 \%)$ は 硬常者群 $(1.8 \pm 1.2 \mu \mathrm{g} / \mathrm{ml}, 5.8 \pm 4.0 \%)$ と比へて $23 \mathrm{kD}$ 蛋白賈が著しく增大した。これに対して術後改 善群 $(1.5 \pm 0.7 \mu \mathrm{g} / \mathrm{ml}, 4.3 \pm 2.0 \%)$ ては有意に娍少し 健常者のレベルに回得した。術後非改善群 (10.1土 $11.5 \mu \mathrm{g} / \mathrm{ml}, 7.8 \pm 5.3 \%)$ では, データのばらつきが 大きくなった。血管軍勋地炎 $(2.6 \pm 2.1 \mu \mathrm{g} / \mathrm{ml}, 4.3 \pm$

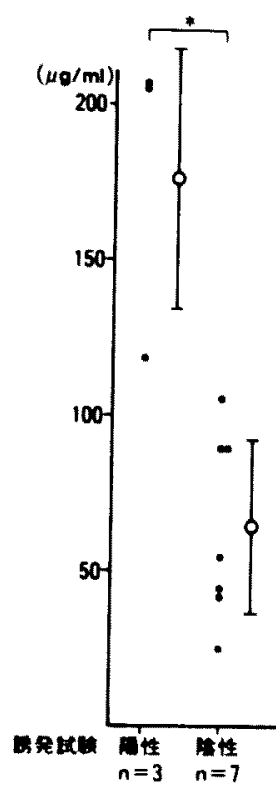

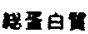

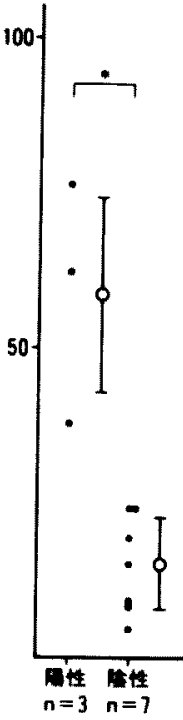

フルフ:ン

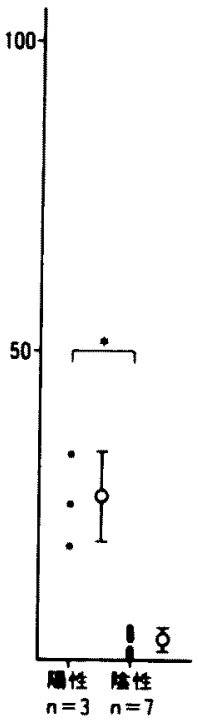

$23 \mathrm{kD}$
图 8 誘発試験の結果による非改善群の策胡中 蛋白質成分

誘発試駼陽性を示す应例上陰性を示す应 例では、總蛋白質泿度、アルフミン, $23 \mathrm{kD}$ 蛋白質源度に有意差が認められた。 Mann-Whitney 検定を行った。 $(*<0.05)$

4. 1\%)仕健常者との間に有意差は䛱められなかった。 5. 林梾性计症状の存統する非改善症例について

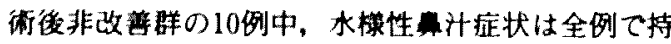

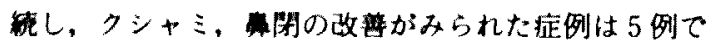
あった。

術後非改暨群は螕蛋白買, アルフミン, 23kDの蛋白 買度のデータのばらつきが大きいため，抗原誘発試 悇を行いその晹性例と陰性例に分けて比較した（図 8).

下甲介化学部手術後，誘発武験か陰性となるにもか かわらず水様性计症状がみられる術後非改善群の症 例群は，誘発武䂵陽性例と比較したときに絰蛋白質港 度,アルフミン, 23kD 蛋白質は有意に低值を示した。 さらに詳しく調へると誘発試験の「陽性例」の総蛋

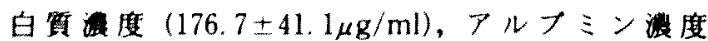
$(58.7 \pm 16.0 \mu \mathrm{g} / \mathrm{ml}, 33.0 \pm 2.9 \%) ， 23 \mathrm{kD}$ 程白貿灌度 $(26.5 \pm 7.2 \mu \mathrm{g} / \mathrm{ml}, 15.3 \pm 2.5 \%)$ は「治浿前群」の總 蛋白買浱 $(102.8 \pm 28.8 \mu \mathrm{g} / \mathrm{ml}$ ) (図 2$)$ ，アルフミン 


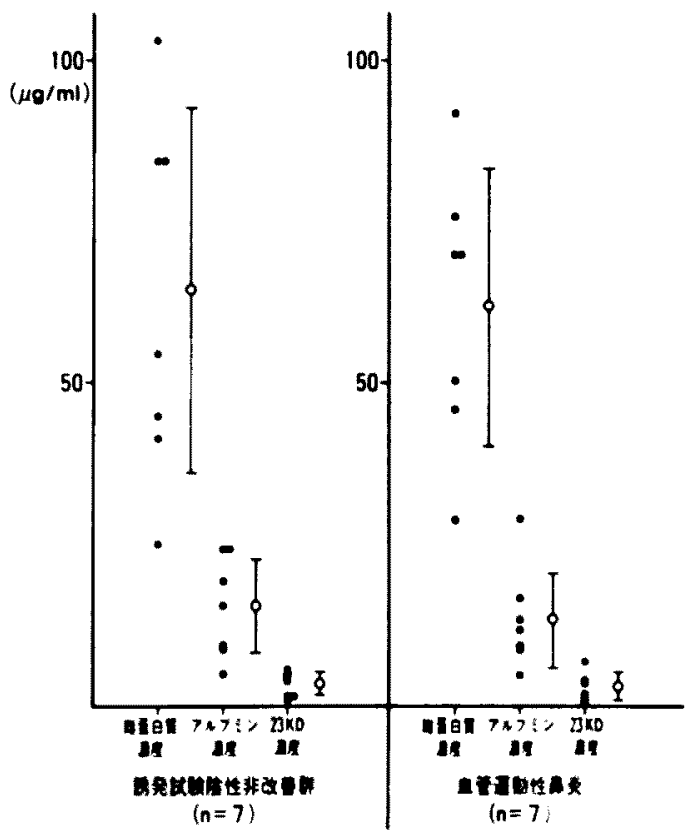

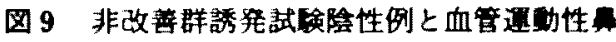
炎の比较

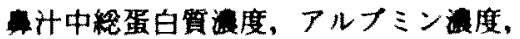
$23 \mathrm{kD}$ 蛋白䆩淁度は両者は非常に近い值 を示した。

度 $(26.3 \pm 8.4 \mu \mathrm{g} / \mathrm{ml}, 26.0 \pm 4.0 \%)(区 3), 23 \mathrm{kD}$ 聚白期度 $(14.6 \pm 12.3 \mu \mathrm{g} / \mathrm{ml}, 5.8 \pm 4.0 \%$ ) (图 7 ) と此䍩すると增大していた。

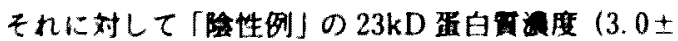
$1.6 \mu \mathrm{g} / \mathrm{ml}, 4.6 \pm 1.6 \%)$ 仕值常者群 $(1.8 \pm 1.2 \mu \mathrm{g} / \mathrm{ml}$, $5.8 \pm 4.0 \%$ )（因7)の低に生て低下しいるにもかか

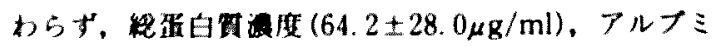
ン作 $(15.1 \pm 7.3 \mu \mathrm{g} / \mathrm{ml}, 23.6 \pm 6.3 \%)$ は改㗉群」

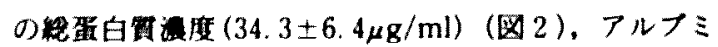
ン度 $(3.2 \pm 0.6 \mu \mathrm{g} / \mathrm{ml}, 10.5 \pm 0.8 \%$ )（图3）ょりい ナ゙れも有意に（ $(p<0.01 ）$ 高的度を示した。

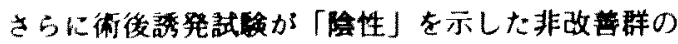

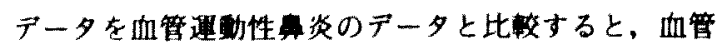

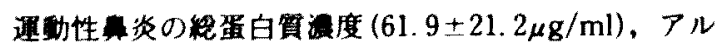
フミン $(13.3 \pm 7.3 \mu \mathrm{g} / \mathrm{ml}, 21.1 \pm 8.6 \%), 23 \mathrm{kD}$ 炎白 出 $(2.6 \pm 2.1 \mu \mathrm{g} / \mathrm{ml}, 4.3 \pm 4.1 \%)$ とほは一致していた (区 9 ).

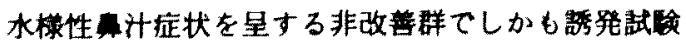

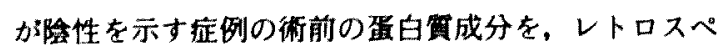
クティフに追求し得た7例について娭钨すると罒100

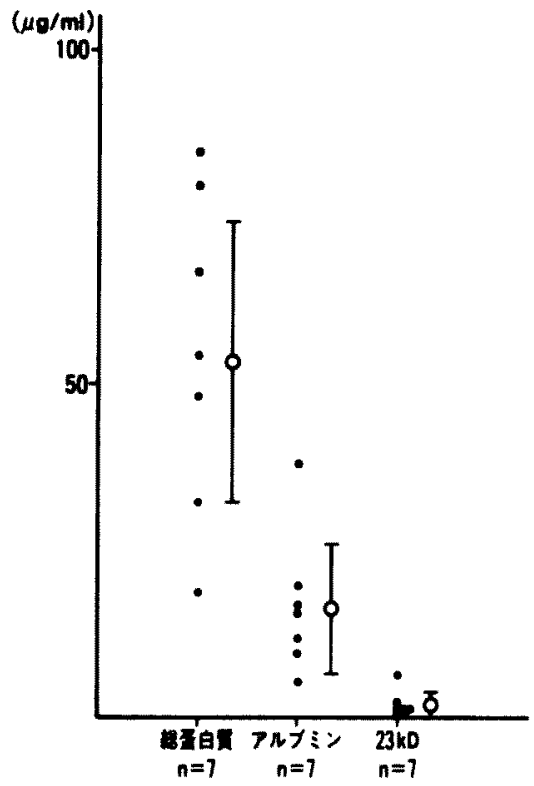

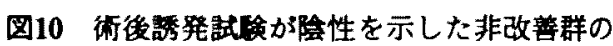
術前の蛋白置成分の娭討

治事前にみることができた 7 例の䌊白 西,アルブミン, $23 \mathrm{kD}$ 蛋白質の溞度を示 す.

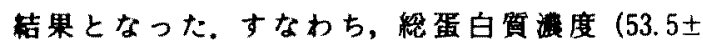

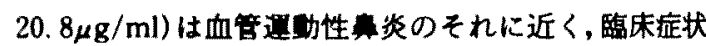
が $(+)$ の度 $(58.7 \pm 19.6 \mu \mathrm{g} / \mathrm{ml})$ （図 1) に近い值 でった.アルプミン流度は $16.7 \pm 9.8 \mu \mathrm{g} / \mathrm{ml}(30.2 \pm$ $7.9 \%$ ) てあり, $23 \mathrm{kD}$ 蛋白累 $(1.9 \pm 1.9 \mu \mathrm{g} / \mathrm{ml}, 3.2 \pm$

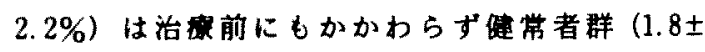
$1.2 \mu \mathrm{g} / \mathrm{ml}, 5.8 \pm 4.0 \%$ ）（図7）とほほ同じ低湠度を 示した。

\section{考 桨}

本研究の目的は，下甲介化学昘手術後に誘発試跙が

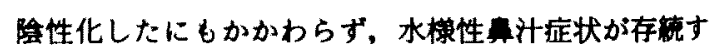
る症例の病热の解明を通して，アレルギ一性竞炎とし て一括してきた症例を娭吘することてある。

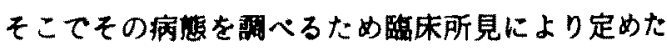
各グループに該当する症例を作為に抽出し具计中の

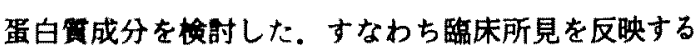
生化学的特徽を見いだすことであった。

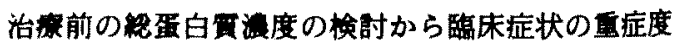

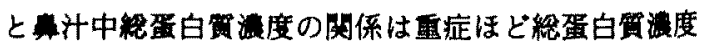
が禹いことがわかった。すなかち水様性业计症状があ 


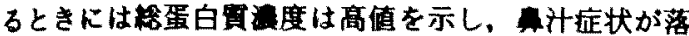
ち首いているときには低固てあることが碓訩てきた。

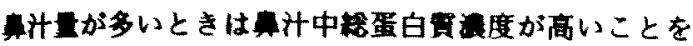
示すと䉽航てさる。

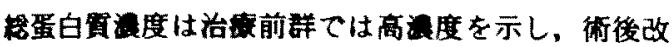

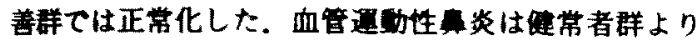
高渡てあるが有意に增大していなかった。

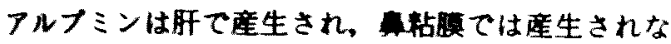

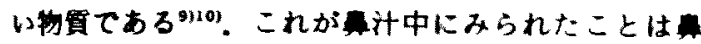

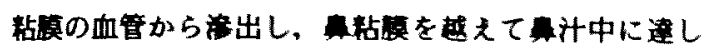

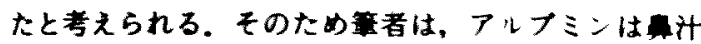
中の血管透过性の因子として考夫た，治䨘前群のアル プミン度 $(26.3 \pm 8.4 \mu \mathrm{g} / \mathrm{ml}, 26.0 \pm 4.0 \%)$ は術後改

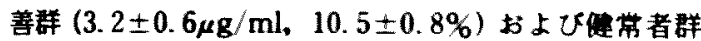
$(4.2 \pm 1.7 \mu \mathrm{g} / \mathrm{ml}, 13.8 \pm 2.6 \%)$ に比べ有彯に高值を示 し(因3），このことから手行により正䓪化することが

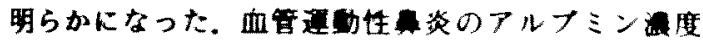
$(13.3 \pm 7.3 \mu \mathrm{g} / \mathrm{ml}, 21.1 \pm 8.6 \%)$ は经营者群 $(4.2 \pm$ 1. $7 \mu \mathrm{g} / \mathrm{ml} ， 13.8 \pm 2.6 \%$ にに比へて有意に高触を示 したがそれが特视てらるように考えられる。

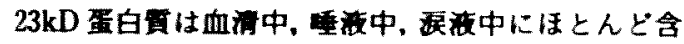
まれず(因 5)，かつビロカルビン特て分必が增大す

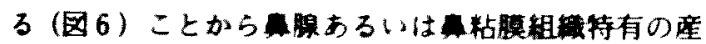

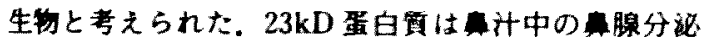
由来として考えられる.山口゙"は咸由来のライソソ ームについて述ヘているが、ライソソームは17kDで

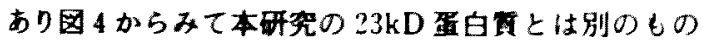

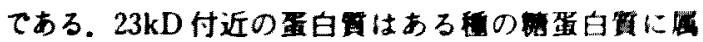
するかもしんないが、この聚日可の同定は合後の直要 な課题でる。

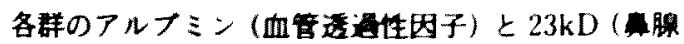

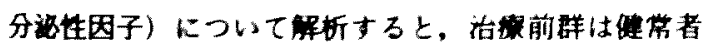

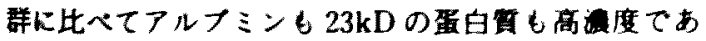

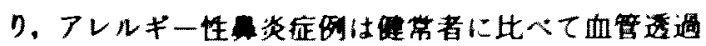

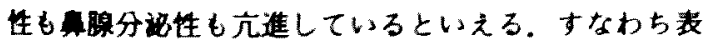

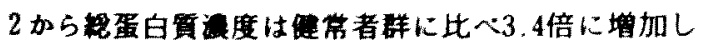

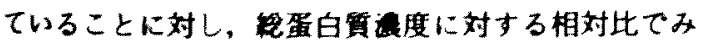

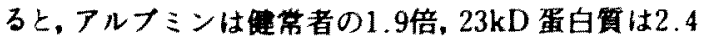
倍に增加していた。

街後改譬群は，健常者群と同㤦，アルプンおよひ

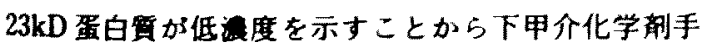
街の奻果により，いずれの因子も娍少したと結詒する

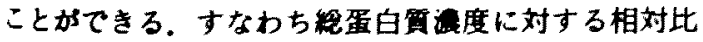
でみると、アルプンは健常者の0.8倍，23kD 虫白算
は0.7倍に減少していた（表 2 )。

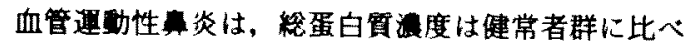
2 倍に增加し，それに对する相对比てみるとアルブ

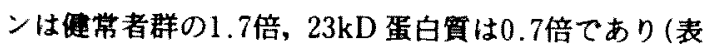
2)、健常者群に比べてアルブミンの海度が比㜞的高瀑

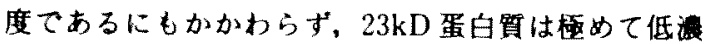
度であることがその特㮹であった，その名のとおり血 管透過性が元進していると解粉てきた。これらのこと

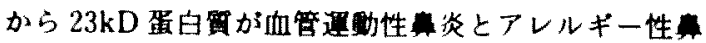
炎を区別するように思われた。

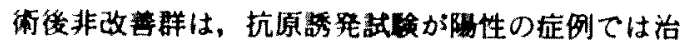
整前群と此べてルナミン，23kD蛋白面の雨者はき

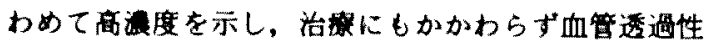

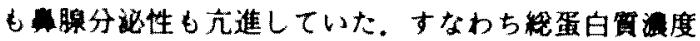

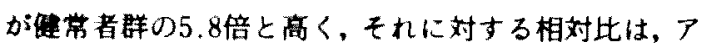
ルプンでは健常者群の2.4倍，23kD 蛋白目が2.6倍 上增加し（表 2$) ， 23 \mathrm{kD}$ 蛋白實のしぬる割合が高いこ とが特微であった。その原因については不明である。

裴 2 各七ル内の上段は蛋白筫谓度 $(\mu \mathrm{g} / \mathrm{ml})$ ，中段

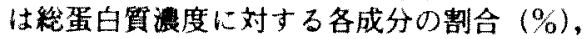
下段の（）の数は健常者群の各成分，すな わち総蛋白質の場合は $30.4 \mu \mathrm{g} / \mathrm{ml}$ ，アルフミ ンは $13.8 \%, 23 \mathrm{kD}$ 蛋白斯の場合は $5.8 \%$ を れそれ1としたときの各群における比を表 す。なおいずれも平均傾のみを表し，標準偏 差を除いた值てある。

\begin{tabular}{|c|c|c|c|}
\hline & 䋨祖白稓 & アルフミン & $23 \mathrm{kD}$ 蛋日第 \\
\hline 侹常者群 & $\begin{array}{l}30.4 \\
\text { (1) }\end{array}$ & $\begin{array}{r}4.2 \\
13.8 \\
(1)\end{array}$ & $\begin{array}{l}1.8 \\
5.8 \\
(1)\end{array}$ \\
\hline 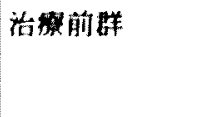 & $\begin{array}{l}102.8 \\
(3.4)\end{array}$ & $\begin{array}{l}26.3 \\
26 \\
(1.9)\end{array}$ & $\begin{array}{l}14.6 \\
14 \\
(2.4)\end{array}$ \\
\hline 改盖群 & $\begin{array}{l}34.3 \\
(1,1)\end{array}$ & $\begin{array}{r}3.2 \\
10.5 \\
(0.8)\end{array}$ & $\begin{array}{r}1.5 \\
4.3 \\
(0.7)\end{array}$ \\
\hline 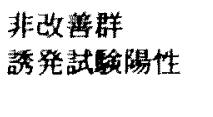 & $\begin{array}{l}176.7 \\
(5.8)\end{array}$ & $\begin{array}{l}58.7 \\
33 \\
(2.4)\end{array}$ & $\begin{array}{l}26.5 \\
15.3 \\
(2.6)\end{array}$ \\
\hline 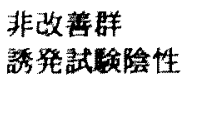 & $\begin{array}{r}64.2 \\
(2.1)\end{array}$ & $\begin{array}{l}15.1 \\
23.6 \\
(1.7)\end{array}$ & $\begin{array}{c}3 \\
4.6 \\
(0.8)\end{array}$ \\
\hline 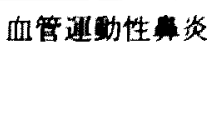 & $\begin{array}{r}61.9 \\
(2.0)\end{array}$ & $\begin{array}{l}13.3 \\
21.1 \\
(1.7)\end{array}$ & $\begin{array}{r}2.6 \\
4.3 \\
(0.7)\end{array}$ \\
\hline
\end{tabular}




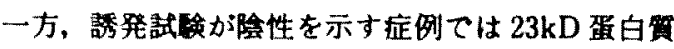

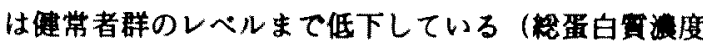
に対する相対比が0.8倍)にもかかからずアルプミンは 比交的高值（蛋白面流度に对する相対比が1.7倍）を

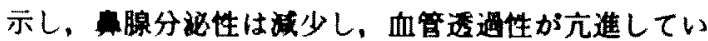
ると考えられた。

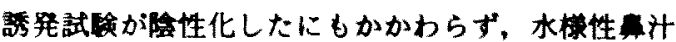

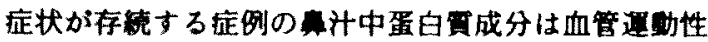
茨の计成分バターンに睈似したものてあった。

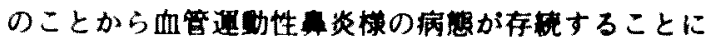

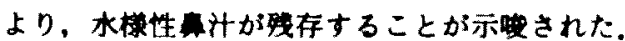

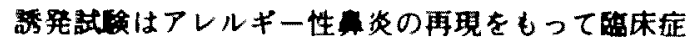
状から抗原に対する粘膜の過敬性をテストする客既

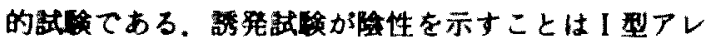
ルギーの网与がないことを意味する。これらのことか

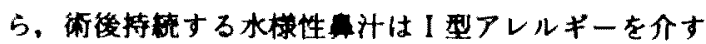

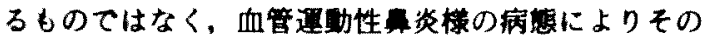
计应状を星していると考えられた。

そこて術後非改善群のうち抗原誘発試挨陰性て水様

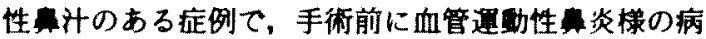
悲を示すか否かを蛋白實についてレトロスベクティフ
に検討した．その結果これらの症例ては，術前のアル フミンは比校的高湍度であるにもかかわらず，23kD

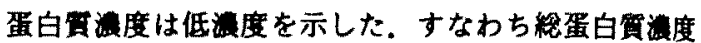
は傮常者群の1.8倍てそそれに対する相対比はアルフミ ンが健常者群の1.8倍, $23 \mathrm{kD}$ 蛋白䨘が0.5倍てあった。 これは前述の血管通趿性算のアルフミン (1.5倍)， $23 \mathrm{kD}$ 蛋白買 (0.7倍) と近かった。

以上のことから初影時にアレルギー性资を旺する 应例のなかには，I型アレルギーと共に血管逴動性臭 炎倳の病慜を併せもつ症例が存在し,これらの症例は， 純伜にI 型アレルギ一の患者が下甲介化学刘手術によ って症状が改善されるのに対し，この手術法によって 改轱しないと推諭された（図11）.

したがって本研究のデータから, 跈察時アルフミン

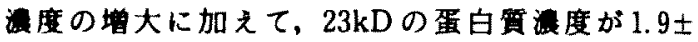
$1.9 \mu \mathrm{g} / \mathrm{ml}$ 末满の症例は水様性汁症状の改善を期待 てきない可能性がある. $1.9 \pm 1.9 \mu \mathrm{g} / \mathrm{ml}$ 以上の場合に は手術の奻果が期特できる。また手術後誘発試硢が陽 性を示した㱏例は $23 \mathrm{kD}$ 蛋白解が $26.5 \pm 7.2 \mu \mathrm{g} / \mathrm{ml}$ と きかめて高流度を示すことから、23kD 蛋白貿は今後 下甲介化学削手術の予後を昣断する上て重要なパラメ

アレルギー性抄

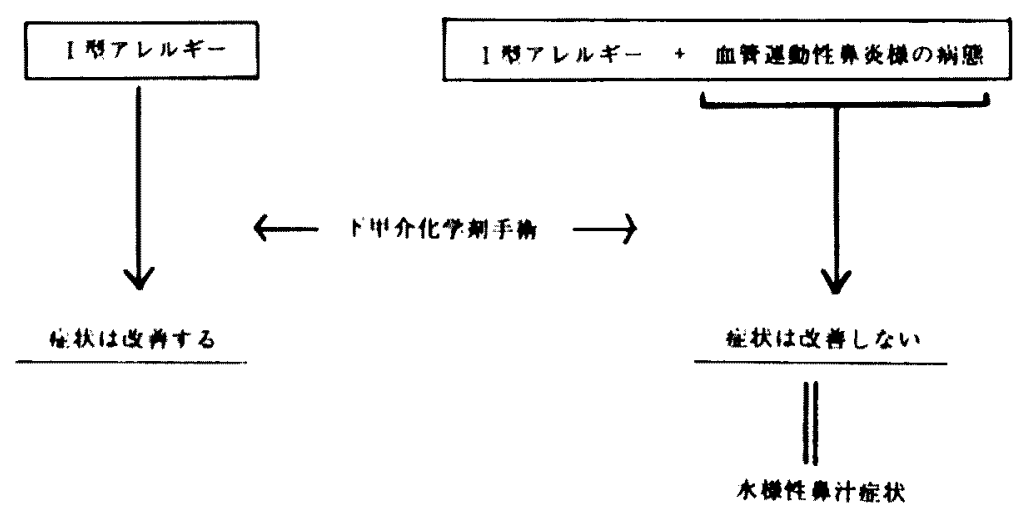

图11いわゆるアレルギー性策炎の病慜 従来いわれてきたアレルギー性筑はＩ型アレルギーの単独

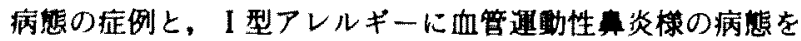
併せもつ应例の 2 群に分けられる.下甲介化学剂手術により I 型アレルギーを病售とするアレルギー性炎は症状が改善 する．一方後者はI型アレルギーは手衍により脱落するが，

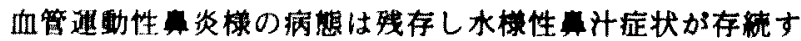
了. 
一タになり得る。

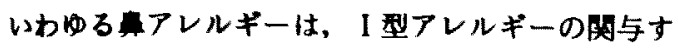
るアレルギー性炎とアレルギーの成与しない血管運

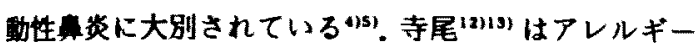

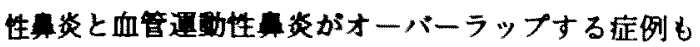
あると述べている．すなかち，二矢患は発症に関して 異なった刺激要因を持ち，ある成值を超えるとアレル

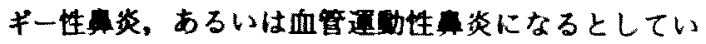
ろ. また両因子が閴を超えだものをアレルギー性血

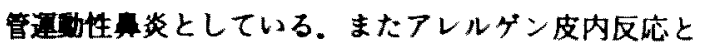
誘発反底から留アレルギーのアレルギー型と血管運勘

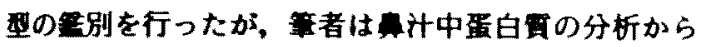
结論することがでさた。

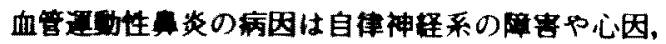

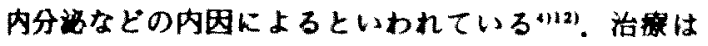
决め手となる方法がなく、根治させることは困䨀であ るといわれるい!

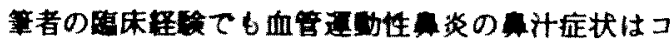

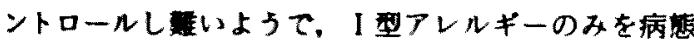
とした花圽店はコントロールしやすいとい5时象があ ろ.アレルギー性炎は若年者からみられるが、血管

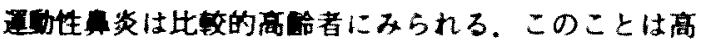

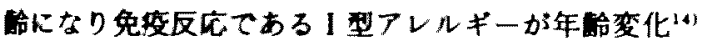

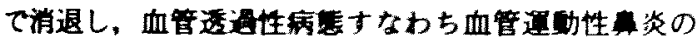
みが残存して跬週する印象がある。先に述へだ型了

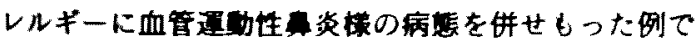

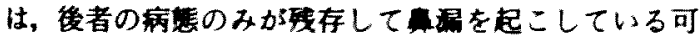
能性がある．高鮯者は免度学的に考えてアレルギー反

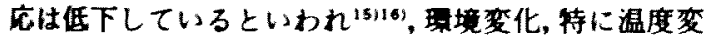

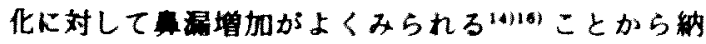

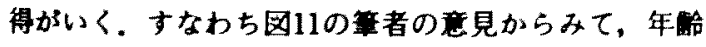
と共にアレルギー反庆が脱落し，自律神経系の障害な

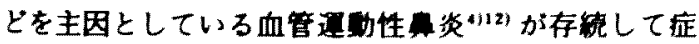
状を示していると考えられる。

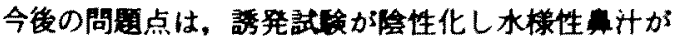

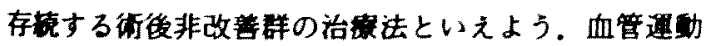

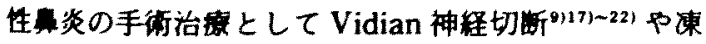

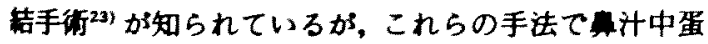
白奥成分がいかに変化するか今後の恰郡が待たれる。

本研究から年中の蛋白留であるアルフミン（血管 透邀性因子）と $23 \mathrm{kD}$ 蛋白䨘（腺分泌性因子）を湘定 することにより，アレルギー性策炎と血管運動性炎

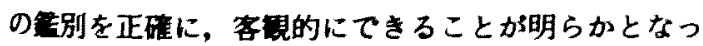

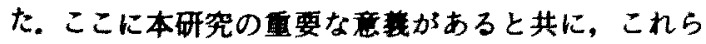

の因子の测定が病態のより一首の理解へ発展すると思 われる.

さらに下甲介化学㓱手術の適応については $23 \mathrm{kD}$ 蛋 白蕒が低值を示す症例は注意する必要があることが明 らかとなった。

まとめ

1. 下甲介化学剂手術後, 誘器試駼が陰性にもかか

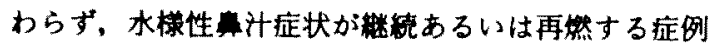
では、その策中の血管由来のアルブミンは健常者と

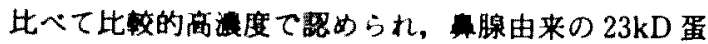
白異は比的低浐度を示すことが分かった。その蛋白 嘪成分は血管要野性炎のパターンを示した。

2. これまでレルギー性炎と一括䋓称していわ れてきたものには、I 型アレルギーを主因とする病㮩

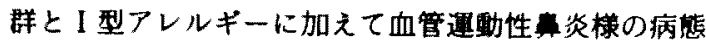
が関与する群の 2 群に分類されることが明らかとなっ た.

3. $23 \mathrm{kD}$ 蛋白質は下甲介化学郕手術の効果判定, 通応のバラメータとなり得ることが分かった。

\section{文献}

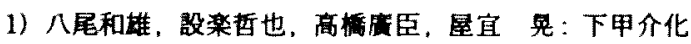

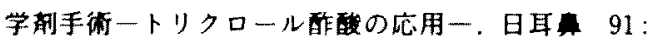
$1031-1041 ， 1988$.

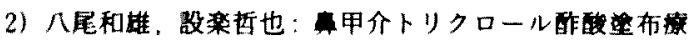
法.アレルギーの監床 $13: 680-683,1993$.

3) Okuda $\mathrm{M}$ : Nasal provocation testing. Am J Rhinol 3:83-92, 1989.

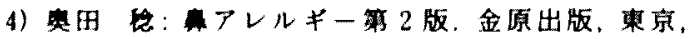
1992.

5)党田 297-344, 1974.

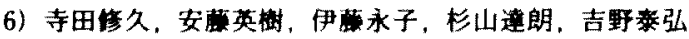

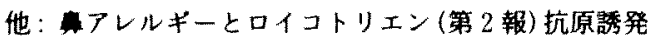

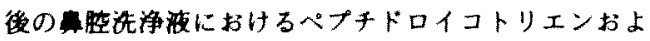
U炎应性細胞の経時的变化. 日耳是 $92: 1337-1344$ 。 1989.

7) Lowry OH, Rosebrough NJ, Farr AL et al: Protein measurement with the folin reagent. J Biol Chem $193: 265-275,1951$

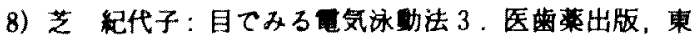
宗，1990，11-27面。

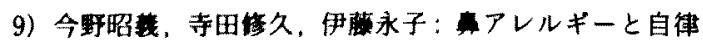
神経.アレルギー彭獭 5：133-145，1986. 


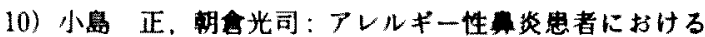
ケミカル・メディエーターに成する研究 (第一埌) 即時 相反灾の计中ヒス夕ミン,ロイコトリエン,キニンに

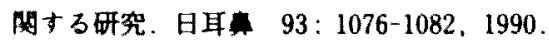

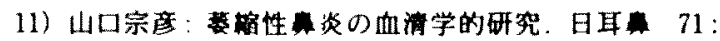
$821 \sim 832,1968$.

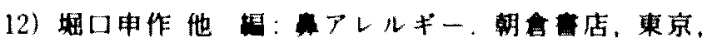
1969. 248-257面.

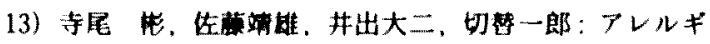

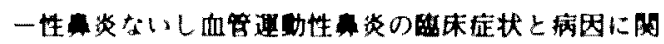

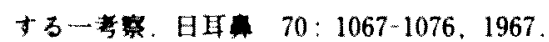

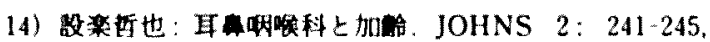
1986 .

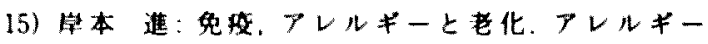
$41: 713-719,1992$.

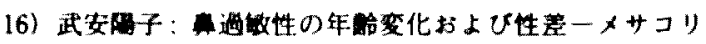

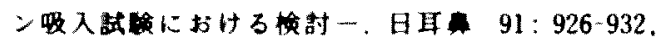
1988.

17) Golding-Wood PH: Observations of vidian neurectomy in chronic vasomotor rhinitis. J Laryngol $75: 232-247,1961$.

18) Konno $A$. Togawa $K$ : Role of the vidian nerve in nasal allergy. Ann Otol Laryngol 88: 258-266. 1976.

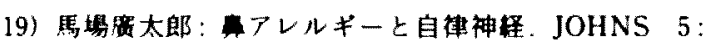
$849-853,1989$

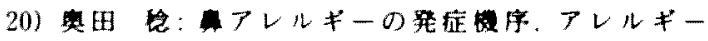
$39: 301-306,1990$.

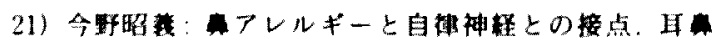

$26: 783-794,1980$.

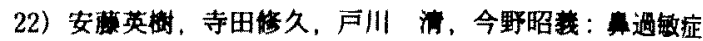

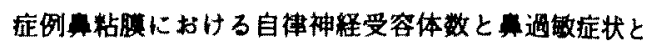

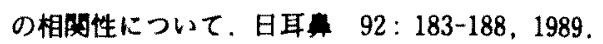

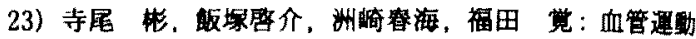

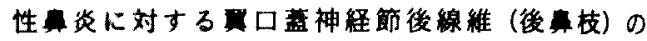
cryosurgery. 耳喉 54 : 577-588，1982.

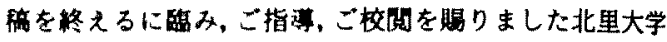

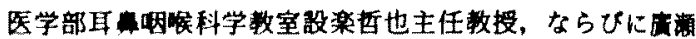

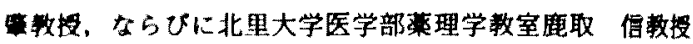
に甚大な解意を旅します。また本研究に対して終始直接こ 指等盷りました北里大学医学部耳望因喉科学教室八尾和雄

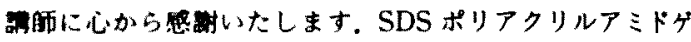

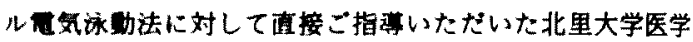

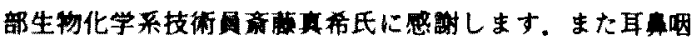

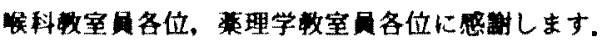

本研究の一部は第29回日本筷科学会 (宇都宫)，第30回日 本 1科学会 (新宿)，第31回日本算科学会 (鈴鹿)，第95回日 本耳时科学会路会 (新渴)，第12回 International Symposium of Infection and Allergy (ISIAN) (ソウル)，第 13回 ISIAN（コふンハーゲン）においてロ激発した。

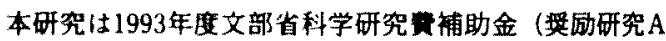
o. 06771437) の助成を受けた。

(1994年10月11日受隔 1994年12月 1 日受理)

別剧群求先 干228 相位原市北里 1-15-1 北里大学医学部耳策哂知科学数室 井口芳明 


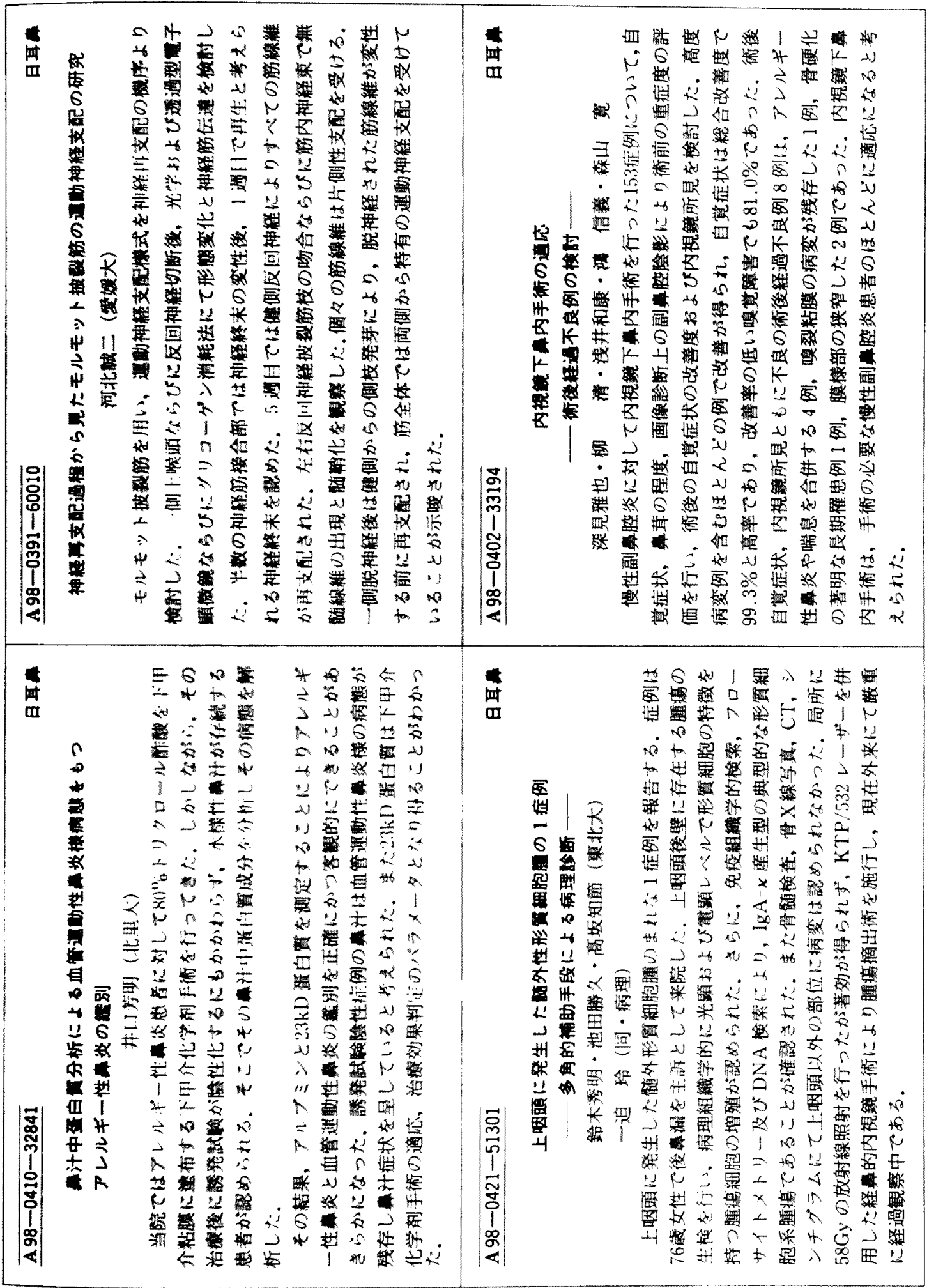

